DOI: $10.20473 / \mathrm{mi} . v 1 \mathrm{i} 2.8826$

Article history: Submitted 01 May 2018; Accepted 15 May 2018; Available online 1 Juny 2018.

\title{
KONTRAK KAPITASI DALAM HUKUM KONTRAK INDONESIA
}

\author{
Andini Aprilia Wardhani dan Erni Agustin \\ erni@fh.unair.ac.id \\ Universitas Airlangga
}

\begin{abstract}
Abstrak
The existence of Act No. 3 of 1992 on Social Security of Labor which regulates that a company is required to provide social security, one of them by providing health insurance for its workers. One form of health insurance provided by the company to its employees is through a healthcare contract, made between the company and the hospital generally referred to as the capitation contract. However, until now there has been no legislation regulating the capitation contract so that the question arises about the validity, characteristics, and implementation of the capitation contract itself. This article aims to examine the characteristics, the validity, and the implementation of capitation contract in Indonesia. Specifically, this type of capitation contract has not been regulated in Indonesian legislation. The parties to the capitation contract are hospitals as providers of healthcare services and companies as recipients of healthcare services. Payments in capitation contracts are fixed and made regularly provided by the recipients of health care services. Capitation contracts are included in contracts that are beneficial to the third parties. Implementation of captation contract in Indonesia refers to the prevailing laws and regulations in Indonesia and should not be contradictory to the regulations such as Social Security of Labor, Health Law and Hospital Law.
\end{abstract}

Keywords: Health Insurance; Capitation Contract.

\begin{abstract}
Abstrak
Adanya Undang-Undang Nomor 3 Tahun 1992 tentang Jaminan Sosial Tenaga Kerja yang mengatur bahwa suatu perusahaan diwajibkan untuk memberikan jaminan sosial, salah satunya dengan memberikan jaminan kesehatan bagi para pekerjanya. Salah satu wujud dari jaminan kesehatan yang diberikan oleh perusahaan kepada karyawannya yaitu melalui kontrak pelayanan kesehatan, yang dibuat antara perusahaan dengan rumah sakit yang umumnya disebut dengan kontrak kapitasi. Namun, hingga saat ini belum ada peraturan perundang-undangan yang mengatur mengenai kontrak kapitasi sehingga timbul pertanyaan mengenai keabsahan, karakteristik, dan impelementasi dari kontrak kapitasi itu sendiri. Artikel ini bertujuan untuk menelaah karakteristik, keabsahahan kontrak kapitasi dan implementasinya di Indonesia. Secara spesifik, jenis kontrak kapitasi ini belum diatur dalam peraturan perundang-undangan di Indonesia. Para pihak dalam kontrak kapitasi adalah pihak rumah sakit sebagai penyelenggara jasa layanan kesehatan dan perusahaan sebagai penerima jasa layanan kesehatan. Pembayaran dalam kontrak kapitasi dilakukan secara tetap yang diberikan oleh penerima jasa layanan kesehatan. Kontrak kapitasi termasuk dalam kontrak yang bersifat menguntungkan pihak ketiga. Implementasi kontrak kaptasi di Indonesia mengacu pada peraturan perundang-undangan yang berlaku di Indonesia dan tidak boleh bertentangan dengan peraturan antara lain Undang-Undang Jaminan Sosial Tenaga Kerja, UndangUndang tentang Kesehatan dan Undang-Undang tentang Rumah Sakit.
\end{abstract}

Kata Kunci: Jaminan Kesehatan; Kontrak Kapitasi.

\section{Pendahuluan}

Undang-Undang Nomor 3 Tahun 1992 Tentang Jaminan Sosial Tenaga Kerja (selanjutnya disebut UU No. 3/1992) pada Pasal 3 ayat 2 menyebutkan bahwa, 
"Setiap tenaga kerja berhak atas jaminan sosial tenaga kerja". Jaminan sosial yang dimaksud tersebut salah satunya dapat berupa jaminan kesehatan. Ini menunjukkan bahwa terdapat adanya suatu aturan yang mengatur bahwa perusahaan diwajibkan untuk memberikan jaminan kesehatan bagi para pekerjanya. Dalam pelaksanaannya, pemberian jaminan kesehatan oleh perusahaan dapat dilakukan melalui beberapa cara. Salah satu cara untuk mengimplementasikannya yaitu dengan bantuan menggunakan jasa dari pihak swasta, yang biasanya terbentuk dalam suatu perjanjian atau kontrak. Pihak swasta yang dimaksud disini berupa perusahaan asuransi swasta atau perusahaan yang memiliki layanan kesehatan didalamnya. Contohnya adalah PT. Petro Graha Medika, PT. Asuransi Jiwa InHealth Indonesia, PT. MNC Life Assurance, dan lain-lain.

Salah satu bentuk jaminan kesehatan yang diberikan oleh perusahaan yaitu berupa pelayanan kesehatan yang diberikan oleh perusahaan secara gratis kepada pekerjanya apabila pekerjanya mengalami masalah kesehatan dapat dibawa ke rumah sakit yang terikat dalam kontrak dengan perusahaan tersebut. Sebagai contoh dalam praktik kontrak yang dibuat antara petrokimia dengan petromedika, yaitu antara perusahaan dengan rumah sakit rekanannya yang didasarkan pada suatu kontrak yang umumnya dikenal dengan istilah "kontrak kapitasi". Skema hubungan hukum tersebut disebut sebagai kontrak kapitasi, karena dalam kontrak tersebut memuat klausul bahwa rumah sakit bersedia untuk memberikan layanan jasa kesehatan bagi pegawai perusahaan yang berobat ke rumah sakit rekanannya tersebut dengan imbal prestasi berupa pembayaran sejumlah uang yang telah ditentukan nominalnya dan dikurangi dengan premi BPJS yang harus dibayarkan oleh perusahaan kepada rumah sakit yang bersangkutan dalam jangka waktu tertentu, meskipun dalam jangka waktu tersebut, ada atau tidak pegawai perusahaan yang berobat dan/atau menggunakan jasa layanan kesehatan di rumah sakit yang bersangkutan. ${ }^{1}$

\footnotetext{
${ }^{1}$ Patrick C. Alguire, 'Understanding Capitation' (American College of Physicians) $<$ http:// www.acponline.org/about-acp/about-internal-medicine/career-paths/residency-career-counseling/ guidance/understanding-capitation> accessed 13 September 2017.
} 
Dalam praktek banyak dijumpai pelaksanaan kontrak kapitasi tersebut dilakukan dengan cara perusahaan membayar kepada rumah sakit dibayarkan secara tetap dan periodik sesuai dengan kesepakatan kedua belah pihak, dan sebagai bentuk imbal prestasi maka rumah sakit menanggung apabila terdapat pekerja di perusahaan tersebut yang mengalami masalah kesehatan. ${ }^{2}$ Definisi asuransi terdapat yang terdapat dalam Pasal 1 angka 1 Undang-Undang Nomor 40 Tahun 2014 Tentang Perasuransian (selanjutnya disebut UU No. 40/2014) berbunyi:

Asuransi adalah perjanjian antara dua pihak, yaitu perusahaan asuransi dan pemegang polis, yang menjadi dasar bagi penerimaan premi oleh perusahaan asuransi sebagai imbalan untuk:

a. memberikan penggantian kepada tertanggung atau pemegang polis karena kerugian, kerusakan, biaya yang timbul, kehilangan keuntungan, atau tanggung jawab hukum kepada pihak ketiga yang mungkin diderita tertanggung atau pemegang polis karena terjadinya suatu peristiwa yang tidak pasti; atau

b. memberikan pembayaran yang didasarkan pada meninggalnya tertanggung atau pembayaran yang didasarkan pada hidupnya tertanggung dengan manfaat yang besarnya telah ditetapkan dan/atau didasarkan pada hasil pengelolaan dana. ${ }^{3}$

Jika dilihat dari penjelasan diatas, keberadaan kontrak kapitasi tersebut secara tidak langsung menunjukkan bahwa seolah-olah rumah sakit berkedudukan sebagai suatu perusahaan asuransi, karena dalam pelaksanaan kontrak kapitasi tersebut, rumah sakit dalam jangka waktu tertentu mendapatkan pendapatan yang tetap dari pembayaran yang dilakukan oleh perusahaan untuk memberikan jasa layanan kesehatan bagi pegawai perusahaan tersebut yang berobat ke rumah sakit yang bersangkutan. Apabila jumlah biaya yang dikeluarkan oleh rumah sakit dalam memenuhi permintaan layanan kesehatan yang dibutuhkan oleh pegawai perusahaan dalam jangka waktu tersebut melebihi pendapatan yang diterimanya dari

2 'Capitation Payments' <http://www.investopedia.com/terms/c/capitation-payments.asp> accessed 13 September 2017.

${ }^{3}$ Undang-Undang Nomor 40 Tahun 2014 Tentang Perasuransian (Lembaran Negara Republik Indonesia Tahun 2014 Nomor 337, Tambahan Lembaran Negara Republik Indonesia Nomor 5618), Pasal 1 angka (1). 
perusahaan, maka kekurangan dana untuk menutupi biaya tersebut ditanggung oleh rumah sakit yang bersangkutan. Dalam artian, walaupun rumah sakit memperoleh keuntungan dari selisih pendapatan yang diberikan oleh perusahaan dengan biaya yang dikeluarkan untuk layanan kesehatan kepada pegawai perusahaan ataupun rumah sakit mengalami kerugian akibat pendapatannya lebih kecil dibandingkan dengan biaya layanan kesehatan yang diperlukannya, maka hal tersebut tidak mempengaruhi nilai biaya jasa tetap yang telah disepakati antara rumah sakit dengan perusahaan dalam kontrak kapitasi.

Hal tersebut menunjukkan bahwa terdapat adanya penanggungan yang dilakukan oleh pihak rumah sakit atas layanan kesehatan pegawai perusahaan yang menandatangani kontrak kapitasi dengan rumah sakit tersebut. Lebih lanjut lagi, antara suatu perusahaan dan perusahaan lain yang sama-sama menandatangani kontrak kapitasi dengan rumah sakit yang bersangkutan juga saling menanggung satu sama lain dari segi pembiayaan. Keadaan tersebut menimbulkan pertanyaan terkait dengan apakah rumah sakit sebagai badan hukum yang bergerak di bidang perumahsakitan dapat menjalankan pula kegiatan pelayanan kesehatan dengan skema tersebut dalam kontrak kapitasi.

Berdasarkan Pasal 7 ayat 4 Undang-Undang Nomor 44 Tahun 2009 Tentang Rumah Sakit (selanjutnya disebut UU No. 44/2009) menyebutkan bahwa, "Rumah Sakit yang didirikan oleh swasta sebagaimana yang dimaksud pada ayat 2 harus berbentuk badan hukum yang kegiatan usahanya hanya bergerak di bidang perumahsakitan". Ketentuan tersebut menunjukkan bahwa untuk dapat menjalankan kegiatan atau usaha di bidang rumah sakit maka suatu badan usaha wajib hukumnya untuk memperoleh status badan hukum yang bidang usahanya hanya bergerak di bidang perumahsakitan.

Sedangkan dilihat dari sisi perasuransian, berdasarkan Pasal 8 ayat 1 UU No. 40/2014 menyebutkan bahwa "Setiap Pihak yang melakukan Usaha Perasuransian wajib terlebih dahulu mendapat izin usaha dari Otoritas Jasa Keuangan”. Ketentuan tersebut menunjukkan bahwa terhadap pihak yang ingin bergerak di bidang perasuransian, maka pihak tersebut wajib memperoleh izin usaha dari Otoritas Jasa Keuangan. 
Berdasarkan ketentuan tersebut, maka dapat diketahui bahwa badan usaha yang hendak bergerak di bidang perumahsakitan tidak akan mungkin dapat menjalankan usaha perasuransian sekaligus karena badan usaha yang dapat bergerak di bidang perumahsakitan haruslah hanya bergerak di bidang perumahsakitan saja. Oleh karenanya, keberadaan kontrak kapitasi tersebut perlu dikaji terutama mengenai keabsahan kontrak kapitasi tersebut menurut sistem hukum kontrak di Indonesia dan akibat hukum atas pelaksanaan kontrak kapitasi tersebut.

Berdasarkan uraian diatas, keabsahan kontrak kapitasi sangat menarik untuk dikaji lebih mendalam dikaitkan dengan peraturan yang ada di Indonesia. Apakah kontrak tersebut sah atau tidak, menyimpang dari prinsip kebebasan berkontrak yang ada, serta hal lain yang mengacu atau berkaitan dengan kontrak kapitasi.

\section{Karakteristik Kontrak Kapitasi}

\section{A. Konsep Kontrak Kapitasi}

Sistem kapitasi (Capitation System) adalah suatu sistem pembayaran pada Pemberi Pelayanan Kesehatan (PPK) baik rumah sakit, dokter ataupun apotek berdasarkan jumlah "capita” atau jiwa yang harus dilayani baik sakit atau tidak sakit. Dalam sistem kapitasi, pembayaran diberikan di depan sebelum pelayanan diberikan (pre-paid). ${ }^{4}$ Pembayaran dengan sistem kapitasi adalah sebuah metode pembayaran untuk pelayanan kesehatan dimana penyedia layanan dibayar dalam jumlah tetap per pasien tanpa memperhatikan jumlah atau sifat layanan yang sebenarnya diberikan. ${ }^{5} \mathrm{Hal}$ ini dipertegas dengan Pasal 1 angka 6 Peraturan Presiden Nomor 32 Tahun 2014 Tentang Pengelolaan dan Pemanfaatan Dana Kapitasi Jaminan Kesehatan Nasional pada Fasilitas Kesehatan Tingkat Pertama Milik Pemerintah Daerah (selanjutnya disebut PP No. 32/2014) yang menyatakan bahwa dana kapitasi merupakan besaran pembayaran per bulan yang dibayar di muka kepada Fasilitas Kesehatan Tingkat Pertama (FKTP) berdasarkan jumlah peserta yang terdaftar tanpa memperhitungkan jenis dan jumlah pelayanan kesehatan yang diberikan.

${ }^{4}$ Sulastomo, Manajemen Kesehatan, (Gramedia Pustaka Utama 2007).[208].

5 Theresa W. Bourdon, An Introduction to Capitation and Health Care Provider Excess Insurance (FCAS 1997).[104]. 


\section{B. Sejarah Kontrak Kapitasi Dan Perkembangannya di Indonesia}

Di Jerman, asuransi sosial dimulai dan dikembangkan pada pemerintahan Bismarch tahun 1883 dengan meluncurkan undang-undang yang mewajibkan para pekerja untuk mengikuti asuransi kesehatan. Jika ditinjau dari aspek model pelayanan dan pembiayaan kesehatan, asuransi di Jerman menggunakan pendekatan pasar pada asuransi swasta, tetapi dengan subsidi Negara. ${ }^{6}$ Besarnya premi berdasarkan prosentase dan sangat bergantung pada penghasilan peserta, sehingga tampak jelas subsidi silang. Asuransi ini dikenal dengan nama Social Health Insurance. ${ }^{7}$

Di Inggris sistem asuransi kesehatan sosial pertama pada tahun 1991 yang berkembang menjadi British National Health Service (NHS) pada tahun 1946. Ciri dari NHS adalah pelayanan kesehatan dilaksanakan oleh pemerintah, dan termasuk kategori model pelayanan kesehatan nasional. ${ }^{8}$

Di Eropa, hampir segala upaya asuransi kesehatan dilakukan dalam bentuk asuransi kesehatan sosial yang sejumlah prosentase tertentu dari gaji/upahnya. Penyelenggaranya adalah badan asuransi, yang bukan perusahaan asuransi yang mencari untung. Badan asuransi tersebut tidak mencari untung (nirlaba) dan karenanya lebih transparan dalam manajemen dan memiliki anggota hampir seluruh penduduk.

Di Amerika, sistem pelayanan kesehatan diasumsikan berorientasi pasar, dan kurang lebih sepertiga dari pembiayaan kesehatan adalah langsung dibayar oleh pasien (out of pocket). Sumber dana sisanya berasal dari asuransi swasta yang profit maupun asuransi not for profit seperti Blue Cross dan Blue Shield serta Health Maintenance Organization (HMO).

Mekanisme pembayaran dengan sistem kapitasi sesungguhnya sudah lama digunakan di Eropa, jauh sebelum HMO (Health Maintenance Organization). Indonesia mengadopsi sistem kapitasi berdasarkan sistem pembayaran kapitasi

\footnotetext{
${ }^{6}$ Henni Djuhaeni, Asuransi Kesehatan Dan Managed Care: Modul Belajar Mengajar (Program Pascasarjana Magister Ilmu Kesehatan Masyarakat Universitas Padjajaran 2007).[12].

${ }^{7}$ Peter Zweifel, The Theory of Social Health Insurance (now Publishers Inc 2007). [8].

${ }^{8}$ Rachmad Suhanda, 'Jaminan Kesehatan Dan Managed Care' (2015) Vol. 2 Jurnal Universitas Padjajaran Bandung.[104-105].
} 
yang berlaku di Jerman dengan pembayaran prepaid berdasarkan kapitasi dan pelayanan yang bersifat komprehensif. ${ }^{9}$

Konsep kapitasi di Indonesia pada awalnya diujicobakan di lima kabupaten/ kota pada tahun 1990. Kemudian pada tahun 1993, penerapan program kapitasi total dikembangkan secara efektif di seluruh Indonesia. ${ }^{10}$ Jumlah kabupaten/kota yang menerapkan sistem pembayaran kapitasi total terus berkembang.

Pelaksanaan sistem kapitasi di Indonesia salah satunya dilakukan oleh perusahaan dengan rumah sakit swasta. Hal ini dilakukan karena adanya kewajiban bagi perusahaan untuk memberikan jaminan sosial kepada para pekerjanya berdasarkan Pasal 3 ayat 2 UU No. 3/1992. Pelaksanaan sistem kapitasi tersebut biasanya terbentuk dalam suatu perjanjian atau kontrak, sehingga biasa disebut dengan kontrak kapitasi.

\section{Skema Hubungan Hukum Dalam Kontrak Kapitasi}

Para pihak yang dapat terlibat dalam kontrak kapitasi yaitu:

1. Antara Perusahaan dengan Perusahaan Asuransi

Kontrak kapitasi dapat dibuat antara sebuah perusahaan dengan perusahaan asuransi yang mana mekanismenya dapat diuraikan sebagai berikut: Perusahaan membuat kontrak kapitasi dengan perusahaan asuransi yang berisi bahwa kewajiban perusahaan asuransi yaitu menanggung segala biaya yang dikeluarkan untuk menjamin kesehatan karyawan perusahaan, sedangkan kewajiban perusahaan yaitu membayar sejumlah uang yang nominalnya telah disepakati dan harus dibayarkan oleh perusahaan kepada perusahaan asuransi dalam jangka waktu tertentu. ${ }^{11}$

Kemudian perusahaan asuransi akan membuat kontrak pelayanan kesehatan dengan rumah sakit yang dipilihnya sebagai rujukan untuk karyawan

${ }^{9}$ ibid. [15].

${ }^{10}$ I Gede Made Wintera dan Julita Hendrartini, 'Determinan Kepuasan Dokter Puskesmas Terhadap Sistem Pembayaran Kapitasi Peserta Wajib PT. Askes Di Kabupaten Donggala Provinsi Sulawesi Tengah' (2005) Vol. 08 Jurnal Manajemen Pelayanan Kesehatan.[105].

${ }^{11}$ Hasbullah Thabary, 'Keterbukaan Dalam Pembayaran Kapitasi' (Universitas Indonesia 2014).[10] 
perusahaan rekanannya yang membutuhkan jasa layanan kesehatan. Perusahaan asuransi yang menanggung segala biaya yang dikeluarkan untuk karyawan perusahaan yang telah berobat di rumah sakit rekannya, sedangkan rumah sakit bersedia menjadi tempat berobat dengan memberikan pelayanan kesehatan kepada karyawan perusahaan rekannya.

2. Antara Perusahaan dengan Rumah Sakit.

Perusahaan membuat kontrak kapitasi dengan rumah sakit baik rumah sakit milik pemerintah atau rumah sakit milik swasta yang didalamnya membuat klausul bahwa perusahaan berkewajiban untuk membayar sejumlah uang yang telah ditentukan nominalnya secara pasti yang harus dibayarkan oleh perusahaan kepada rumah sakit dalam jangka waktu tertentu, dengan imbal prestasi rumah sakit bersedia untuk memberikan jasa layanan kesehatan bagi karyawan perusahaan. ${ }^{12}$

Berdasarkan kedua skema hubungan hukum dalam kontrak kapitasi tersebut, dapat dilihat perbedaannya adalah adanya peran perusahaan asuransi dalam kontrak. Pada skema yang pertama, perusahaan asuransi kesehatan yang menanggung segala biaya yang dikeluarkan akibat adanya pelayanan kesehatan yang diberikan oleh rumah sakit yang bersangkutan. Perusahaan asuransi akan memberikan kriteria batas biaya maksimum yang ditanggung oleh perusahaan asuransi kesehatan kepada perusahaan yang berobat di rumah sakit tersebut. ${ }^{13}$ Sedangkan pada skema yang kedua, perusahaan membayar dengan sejumlah biaya yang telah ditetapkan dalam kontrak, tanpa ada campur tangan dari perusahaan asuransi. Sehingga perbedaannya dengan skema yang kedua adalah para pemberi pelayanan kesehatan telah mengetahui jumlah dana yang tersedia dan diberikan (dibayarkan) di muka. Dengan demikian, ada batasan dari segi pembiayaan untuk memberikan pelayanan pada pasien.

Berdasarkan uraian diatas, yang terlibat dalam kontrak yaitu antara perusahaan dengan perusahaan asuransi atau antara perusahaan dengan rumah sakit dengan menguntungkan pihak ketiga dalam hal ini yaitu pekerja perusahaan

\footnotetext{
${ }^{12}$ ibid.

${ }^{13}$ Sulastomo.Op.Cit.[19].
} 
yang mendapat jaminan pelayanan kesehatan. Dalam hal ini kontrak kapitasi termasuk dalam kontrak yang dibuat untuk menguntungkan pihak ketiga (derden beding) diperbolehkan berdasarkan Pasal 1317 BW.

\section{Ruang Lingkup Kontrak Kapitasi}

Berdasarkan penjelasan pada bab-bab sebelumnya, maka dapat disimpulkan bahwa unsur-unsur pokok dari kontrak kapitasi adalah :

1. Adanya pihak penyelenggara pelayanan kesehatan;

2. Adanya pihak penerima jasa pelayanan kesehatan;

3. Adanya biaya yang ditentukan secara tetap dan dibayarkan di awal sebelum pemberian jasa pelayanan kesehatan itu dilaksanakan.

Selain itu, kontrak kapitasi berorientasi pada proses pelaksanaan kontrak (inspanning verbintenis), bukan hasil yang ditimbulkan sebagai akibat dari adanya pelaksanaan dari kontrak. Dengan kata lain, kontrak kapitasi lebih menekankan pada proses pelaksanaan pelayanan kesehatan yang diberikan. Sehingga apabila dalam proses pelaksanaan kontrak kapitasi tersebut mengakibatkan pasien (dalam hal ini peserta pelayanan kesehatan) mengalami penurunan kesehatan bahkan sampai kematian, maka keadaan tersebut merupakan hal di luar yang diperjanjikan dalam kontrak kapitasi.

Berdasarkan penjelasan diatas, dapat dilihat perbedaan antara kontrak kapitasi dengan kontrak asuransi kesehatan yaitu:

1. Subjek kontrak

Dalam kontrak kapitasi, pihak yang terikat dalam kontrak yaitu antara perusahaan dengan rumah sakit, maupun antara perusahaan dengan perusahaan asuransi. Pihak yang terikat dalam kontrak kapitasi disebut sebagai pemberi layanan kesehatan dan penyedia layanan kesehatan. Sedangkan dalam perusahaan asuransi, pihak yang terikat dalam kontrak asuransi yaitu antara perusahaan asuransi dengan pemegang polis.

2. Objek kontrak

Dalam kontrak kapitasi, objek yang diperjanjikan adalah mengenai jasa 
pelayanan kesehatan yang diberikan oleh rumah sakit kepada karyawan perusahaan. Sedangkan dalam asuransi, objek yang diperjanjikan dapat berupa benda dan jasa, jiwa dan raga kesehatan manusia, tanggung jawab hukum, serta semua kepentingan yang dapat hilang, rusak, rugi, atau berkurang nilainya. ${ }^{14}$

3. Tujuan

Tujuan dari kontrak kapitasi yaitu pelayanan kesehatan untuk menjamin tersedianya fasilitas layanan kesehatan yang diberikan perusahaan kepada karyawannya. Sedangkan tujuan dari asuransi yaitu untuk mendapatkan perlindungan atau pengelolaan atas risiko yang dialami oleh tertanggung. Usaha perasuransian adalah segala usaha yang menyangkut jasa pertanggungan atau pengelolaan risiko.

4. Pembayaran

Pembayaran dalam kontrak kapitasi dilakukan tiap bulan dengan nominal yang telah diperjanjikan dengan dikurangi premi BPJS Kesehatan. Pembayaran tersebut ditujukan untuk menjamin tersedianya fasilitas layanan kesehatan yang baik untuk karyawan perusahaan sebagai biaya tambahan manfaat kesehatan selain manfaat dari kepersertaan BPJS Kesehatan. Sedangkan, pembayaran dalam asuransi dilakukan berdasarkan perjanjian yang telah disepakati. Pembayaran tersebut diartikan sebagai premi perusahaan asuransi sebagai imbalan untuk memberikan penggantian kepada tertanggung karena kerugian, kerusakan, biaya yang timbul, kehilangan keuntungan, atau tanggung jawab hukum kepada pihak ketiga yang mungkin diderita tertanggung karena terjadi suatu peristiwa tidak pasti atau memberikan pembayaran yang didasarkan pada meninggalnya atau hidupnya tertanggung dengan manfaat yang besarnya telah ditetapkan atau didasarkan pada hasil pengelolaan dana.

\section{Implementasi Kontrak Kapitasi dalam Sistem Hukum Kontrak Indonesia}

\section{A. Syarat Sah Kontrak}

Berikut adalah analisa syarat keabsahan kontrak berdasarkan Pasal 1320 BW yang terdapat dalam contoh kontrak kapitasi antara PT. Petrokimia Gresik dengan

\footnotetext{
${ }^{14}$ Munawar Kholil, 'Modul Hukum Asuransi’ (Universitas Negeri Sebelas Maret 2010).[8].
} 
PT. Petro Graha Medika:

1. Sepakat mereka yang mengikatkan dirinya.

Kontrak yang dibuat antara PT. Petrokimia Gresik dengan PT. Petro Graha Medika dengan Ir. Hidayat Nyakman sebagai Direktur Utama PT. Petrokimia Gresik yang selanjutnya disebut sebagai Pihak Pertama dan dr. Singgih Priyanto sebagai Direktur Utama PT. Petro Graha Medika yang selanjutnya disebut sebagai Pihak Kedua, para pihak sepakat untuk mengikatkan diri dalam Perjanjian Kerjasama tentang Pelayanan Kesehatan bagi Komisaris, Direksi, dan Karyawan PT. Petrokimia Gresik. Pihak pertama adalah sebuah perusahaan pupuk dan produk kimia yang membutuhkan jasa pelayanan kesehatan untuk Komisaris, Direksi, dan Karyawan PT. Petrokimia Gresik beserta keluarga, sedangkan pihak kedua adalah sebuah perusahaan yang menyediakan jasa pelayanan kesehatan. Bahwa berdasarkan uraian diatas, dapat disimpulkan bahwa syarat pertama sahnya suatu kontrak yaitu tentang kesepakatan kedua pihak telah terpenuhi.

2. Kecakapan untuk membuat suatu perikatan.

Seseorang yang dikatakan telah cakap ketika sudah berusia diatas 18 tahun atau sudah melangsungkan perkawinan. Dalam kontrak ini dibuat antara Ir. Hidayat Nyakman sebagai Direktur Utama PT. Petrokimia Gresik dan dr. Singgih Priyanto sebagai Direktur Utama PT. Petro Graha Medika dapat dikatakan bahwa kedua pihak telah cakap hukum dan pihak yang berwenang untuk mewakili atas nama perusahaan. Karena kedua pihak berkedudukan sebagai Direktur Utama sebuah perusahaan, yang mana para pihak dapat melakukan suatu perbuatan hukum yang dapat dipertanggungjawabkan. Dijelaskan juga dalam Pasal 92 Undang-Undang 40 Tahun 2007 Tentang Perseroan (selanjutnya disebut UU No. 40/2007) bahwa direksi berwenang untuk melakukan perbuatan hukum dalam menjalankan kepengurusan dalam perseroan sesuai dengan kebijakan yang dipandang tepat dalam batas yang ditentukan dengan UU No. 40/2007 atau anggaran dasar. Sehingga kontrak antara PT. Petrokimia dengan PT. Petro Graha Medika telah memenuhi syarat kedua sahnya suatu kontrak. 
3. Suatu hal tertentu.

Objek yang disepakati dalam perjanjian adalah hal tertentu/khusus dan setidaknya jenis pekerjaan tersebut dikenal dan harus merupakan barang yang dapat diperdagangkan saja yang dapat menjadi pokok perjanjian berdasarkan Pasal 1332 BW. Dalam kontrak ini objek yang disepakati adalah pekerjaan pemberian layanan kesehatan. Pekerjaan ini merupakan jasa yang dapat diperdagangkan dan memenuhi syarat yang ada dalam Pasal 1332 BW.

4. Suatu sebab yang diperbolehkan.

Syarat terakhir dari sahnya suatu perjanjian yaitu isi dari perjanjian itu tidak boleh bertentangan dengan hukum, kebijakan publik, dan moralitas. Dalam hal ini kontrak kapitasi pemberian jasa layanan kesehatan antara PT. Petrokimia Gresik dengan PT. Petro Graha Medika tidak bertentangan dengan hukum. Keberadaan kontrak kapitasi tersebut muncul setelah adanya peraturan perundang-undangan yang mengatur bahwa perusahaan diwajibkan untuk memberikan jaminan kesehatan bagi karyawannya. Hal ini dapat dilihat pada ketentuan dalam Pasal 3 UU No. 3/1992 dan Pasal 11 Perpres No. 12 Tahun 2013 Tentang Jaminan Kesehatan.

Kontrak kapitasi dibuat antara perusahaan dengan rumah sakit untuk memberikan jaminan pelayanan kesehatan kepada karyawan perusahaan. Setiap pekerja sudah mendapatkan jaminan kesehatan oleh BPJS Kesehatan, namun perusahaan diperbolehkan untuk memberikan jaminan pelayanan kesehatan tambahan dalam bentuk kontrak pelayanan kesehatan

Maka dapat disimpulkan bahwa kontrak kapitasi yang dibuat antara PT. Petrokimia dengan PT. Petro Graha Medika telah memenuhi syarat keempat sahnya suatu perjanjian. Isi dari kontrak tersebut sesuai dengan aturan yang ada dalam peraturan perundang-undangan di Indonesia sehingga kontrak tersebut sah dan mengikat para pihak yang membuatnya.

Akibat hukum yang ditimbulkan bilamana syarat-syarat subjektif tidak terpenuhi dalam suatu kontrak mengakibatkan kontrak tersebut dapat dibatalkan. Syarat subjektif berdasarkan Pasal 1320 BW yaitu (1) kesepakatan dan (2) kecakapan. Kontrak yang dapat dibatalkan mempunyai pengertian bahwa untuk 
batalnya kontrak tersebut diperlukan upaya hukum, yaitu berupa pembatalan agar kontrak tersebut dapat dibatalkan. ${ }^{15}$ Sementara itu, untuk perihal yang kedua mengenai pihak yang tidak cakap, dan/atau wakilnya yang sah mempunyai hak untuk melakukan upaya pembatalan kontrak. ${ }^{16}$ Ketentuan mengenai hal ini diatur dalam Pasal 1446 sampai dengan Pasal 1450 BW. Pada Pasal 1446 ayat 1 BW dinyatakan bahwa setiap perjanjian yang dibuat oleh orang-orang yang belum cakap dan orang dewasa yang berada di bawah pengampuan adalah batal demi hukum. Namun pada Pasal 1447 ayat 1 BW dinyatakan bahwa hanya atas penuntutan dari orang-orang yang belum dewasa tersebut atau orang-orang yang ditaruh di bawah pengampuan, maka perjanjian tersebut dibatalkan (vernietigd) oleh hakim. ${ }^{17}$

Selanjutnya terhadap kontrak yang dibuat tidak dengan kesepakatan bebas, yaitu yang terjadi karena kekhilafan, paksaan, dan penipuan, pada Pasal 1449 BW menyatakan secara tegas bahwa perjanjian tersebut dapat dibatalkan berdasarkan suatu tuntutan. Lebih lanjut pada Pasal 1450 BW dapat dilihat bahwa pada dasarnya suatu tuntutan dengan "alasan dirugikan" tidak lain merupakan alasan yang semata-mata muncul karena telah terjadi suatu kekhilafan, paksaan atau penipuan sehingga menurut ketentuan Pasal 1449 BW yang mengajukan tuntutan haruslah pihak yang dirugikan tersebut.

Jadi dapat diartikan bahwa suatu kontrak yang tidak memenuhi syarat subyektif sebagaimana telah disebutkan diatas adalah sah secara hukum bilamana pihak yang dirugikan atau pihak yang merasa haknya dilanggar tidak melakukan upaya pembatalan. Sedangkan akibat hukum yang ditimbulkan bilamana syarat-syarat objektif tidak terpenuhi dalam suatu perjanjian mengakibatkan perjanjian tersebut batal demi hukum. Syarat objektif berdasarkan Pasal 1320 BW yaitu (1) suatu perjanjian yang tidak memenuhi syarat objektif secara otomatis perjanjian tersebut adalah batal demi hukum atau tidak sah. Kontrak yang tidak memenuhi syarat objektif

\footnotetext{
${ }^{15}$ Suleman Batubara dan Orinton Purba, Arbitrase Internasional: Penyelesaian Sengketa Investasi Asing Melalui ICSID, UNCITRAL, Dan SIAC (Raih Asa Sukses 2013).[158].

${ }^{16}$ Gunawan Widjaja, Seri Hukum Bisnis Memahami Prinsip Keterbukaan (Aanvullend Recht) Dalam Hukum Perdata (RajaGrafindo Persada 2007).[290].

${ }^{17}$ ibid. [293].
} 
seperti yang diatur dalam BW, demi hukum kontrak yang dibuat itu batal. Oleh karena itu, perjanjian seperti ini dengan sendirinya tidak dapat mengikat para pihak yang membuat. Dalam kontrak yang batal demi hukum, para pihak dianggap tidak pernah membuat kontrak dan keadaan kembali seperti semula sebelum kontrak itu dibuat.

Selain ketentuan yang diatur dalam BW juga terdapat peraturan perundangundangan lain yang memperbolehkan adanya kontrak kapitasi ini dibuat seperti halnya UU 36/2009, UU No. 3/1992, dan Perpres Jaminan Kesehatan. Sehingga dapat disimpulkan bahwa kontrak kapitasi tersebut sah dan tidak melanggar peraturan perundang-undangan yang berkaitan dengan kontrak kapitasi.

Sebelum adanya kontrak kapitasi, telah ada jaminan kesehatan yaitu Badan Penyelenggara Jaminan Sosial (BPJS) yang merupakan program jaminan kesehatan yang disediakan oleh Pemerintah untuk setiap orang termasuk orang asing yang bekerja di Indonesia dan membayar iuran. BPJS tidak hanya ditujukan untuk pekerja perusahaan saja, tetapi juga termasuk veteran, perintis kemerdekaan. ${ }^{18}$ Manfaat yang dirasakan oleh Peserta BPJS tergantung pada nominal iuran yang dibayarkan, namun ada juga yang iuran untuk pelayanan kesehatannya dibayar oleh Pemerintah. Keberadaan kontrak kapitasi yang dibuat oleh perusahaan untuk pekerjanya merupakan biaya tambahan manfaat kesehatan selain manfaat sebagai peserta BPJS. Perusahaan membuat kontrak kapitasi untuk memberikan jaminan pelayanan kesehatan bagi para pekerjanya supaya pekerja perusahaan tersebut tidak mengalami kesulitan ketika membutuhkan jasa layanan kesehatan. Hal ini tidak melanggar peraturan perundang-undangan karena dalam UU No. 3/1992 mengatur bahwa perusahaan diwajibkan untuk memberikan jaminan kesehatan bagi para pekerjanya, salah satunya melalui kontrak kapitasi tersebut.

\section{B. Pencantuman Klausul Reimburst Dalam Kontrak Kapitasi}

Sampai saat ini belum ada peraturan perundang-undangan di Indonesia yang mengatur secara spesifik mengenai kontrak kapitasi. Sehingga pelaksanaan kontrak

18 ‘BPJS Kesehatan’<http://www.bpjs-kesehatan.go.id/bpjs/index.php/pages/detail/2014/13> accessed 15 January 2017. 
kapitasi ini banyak menimbulkan pertanyaan terkait dengan keabsahannya, karena dalam pelaksanaan kontrak kapitasi kerap kali orang berpendapat bahwa dalam kontrak tersebut rumah sakit dapat dianggap menjalankan usaha perasuransian sekaligus. Namun jika diteleliti lebih lanjut, pelaksanaan kontrak kapitasi pada jaminan pelayanan kesehatan berbeda dengan kegiatan perasuransian. Pada Pasal 7 ayat 4 UU No. 44/2009 hanya disebutkan bahwa rumah sakit yang didirikan oleh pihak swasta harus berbentuk badan hukum yang kegiatan usahanya hanya bergerak di bidang perumahsakitan. Sedangkan pada Pasal 8 ayat 1 UU No. 40/2014 hanya menyebutkan bahwa pihak yang ingin bergerak di bidang perasuransian wajib memperoleh izin usaha dari Otoritas Jasa Keuangan (OJK). Berdasarkan peraturan perundang-undangan tersebut dapat dilihat bahwa terdapat syarat-syarat yang harus dipenuhi dalam menjalankan usaha perasuransian. Peran rumah sakit dalam kontrak kapitasi hanya sebatas sebagai pemberi jasa pelayanan kesehatan, tidak disebut sebagai perusahaan asuransi kesehatan. Dalam Pasal 1 angka 1 UU No. 44/2009 dijelaskan bahwa rumah sakit hanya menyelenggarakan pelayanan kesehatan berupa rawat inap, rawat jalan, dan gawat darurat.Rumah sakit dalam hal ini tidak bergerak di bidang perasuransian, karena dalam pelaksanaan kontrak kapitasi tersebut rumah sakit tidak memenuhi unsur menanggung-tertanggung seperti yang terdapat dalam kontrak asuransi.

Cara pembayaran yang ada dalam kontrak kapitasi, yang sebelumnya dilakukan secara tetap dan periodik yang harus disetorkan oleh perusahaan kepada rumah sakit dapat dicantumkan juga mengenai klausul reimburst (penggantian biaya). Pencantuman klausul reimburst dalam kontrak kapitasi dilakukan sebagai transparansi atas dana kapitasi yang diberikan oleh perusahaan kepada rumah sakit rekanannya. Bukan tidak mungkin jika rumah sakit mendapatkan keuntungan yang sangat banyak atas hasil yang didapatkannya dari kontrak kapitasi, jika dalam satu bulan terdapat sedikit karyawan yang membutuhkan jasa pelayanan kesehatan. Jadi, melalui klausul reimburst tersebut dana untuk pelayanan kesehatan semakin jelas peruntukannya.

Dengan demikian, rumah sakit tetap menjalankan kegiatan di bidang perumahsakitan dan tidak lagi dipandang sebagai perusahaan asuransi, karena 
dana kapitasi yang diberikan dalam kontrak tersebut semakin jelas peruntukkannya sebagai pembiayaan yang timbul akibat pelayanan kesehatan yang diberikan kepada peserta jaminan kesehatan pada suatu perusahaan.

\section{Tanggung Gugat Dalam Pelaksanaan Kontrak Kapitasi}

Dalam Pasal 1234 BW telah disebutkan tujuan dari adanya suatu perikatan yaitu untuk memberikan sesuatu, untuk berbuat sesuatu, atau untuk tidak berbuat sesuatu. Tujuan dari perikatan tersebut merupakan suatu prestasi yang harus dipenuhi oleh para pihak. Dimana perikatan atau kontrak tersebut mengikat para pihak (pacta sunt servanda) dan kontrak tersebut mempunyai daya berlaku dan mengikat setara dengan undang-undang.

Penggolongan wanprestasi menurut hukum perdata apabila :

1. Tidak melakukan apa yang disepakati untuk dilakukan;

2. Melakukan apa yang diperjanjikan, tetapi terlambat;

3. Melakukan apa yang diperjanjikan, tetapi tidak sebagaimana yang diperjanjikan; 4. Melakukan sesuatu yang menurut hakikat perjanjian tidak boleh dilakukan. ${ }^{19}$

Pada pelaksanaan kontrak kapitasi, apabila salah satu pihak melakukan wanprestasi, pihak lainnya yang terikat dalam kontrak dapat mengajukan gugatan wanprestasi di Pengadilan Negeri atau melalui penyelesaian perselisihan yang telah disepakati dalam kontrak.

Selain wanprestasi, gugatan yang dapat diajukan atas pelaksanaan kontrak kapitasi yaitu perbuatan melanggar hukum (onrechtmatige daad). Yang dapat mengajukan gugatan perbuatan melanggar hukum (PMH) adalah pasien ataupun perusahaan rekanan rumah sakit dalam kontrak kapitasi. ${ }^{20}$ Dokter harus bertanggung jawab kepada pasiennya secara perdata jika ia melakukan perbuatan melanggar hukum. Berdasarkan Pasal 1365 BW, setiap orang yang melakukan perbuatan melanggar hukum yang menyebabkan kerugian bagi orang tersebut wajib memberikan penggantian kerugian. Berdasarkan yurisprudensi, perbuatan

\footnotetext{
${ }^{19}$ Subekti, Aneka Perjanjian Cet. Kesepuluh (Citra Aditya Bakti 1995). [45].

${ }^{20}$ Bapak Nuril Huda, 'Wawancara Dengan Manager Operasional SDM Petrokimia Gresik, Di Kantor Petrokimia 5 Desember' (2017).
} 
melanggar hukum diartikan sebagai setiap tindakan atau kelalaian yang:

1. Melanggar hak orang lain;

2. Bertentangan dengan kewajiban pribadi;

3. Menyalahi adat kebiasaan yang berlaku;

4. Tidak sesuai dengan kepatutan dan kebiasaan dalam lingkungan pergaulan masyarakat. ${ }^{21}$

Suatu kelalaian yang dilakukan oleh dokter dalam menggunakan keterampilan dan ilmu pengetahuannya untuk mengobati pasiennya disebut sebagai tindakan malpraktik. ${ }^{22}$ Kelalaian yang dimaksud adalah sikap kurang hati-hati dimana tindakan yang dilakukan oleh dokter berada dibawah standar pelayanan medis. Tidak semua kelalaian merupakan suatu kejahatan, jika suatu kelalaian menyebabkan kerugian atau cedera bagi orang lain dapat diterima oleh orang tersebut. Tetapi jika kelalaian yang terjadi menyebabkan orang lain celaka atau harus merenggut nyawa, maka dapat dikategorikan dalam kelalaian berat (culpa lata) yang tolak ukurnya bertentangan dengan hukum, akibatnya dapat dibayangkan, akibatnya dapat dihindari, dan perbuatannya dapat disalahkan. Malpraktik yang dilakukan dengan sikap batin culpa hanya diterapkan pada Pasal 359 KUHP (jika menyebabkan kematian pasien), Pasal 360 KUHP (jika menyebabkan luka berat), dan tindak pidana aborsi pada Pasal 347 dan Pasal 348 KUHP. Malpraktik kedokteran hanya terjadi pada tindak pidana materiil. Unsur pidana dalam malpraktik kedokteran meliputi kematian, luka berat, rasa sakit atau luka yang mendatangkan penyakit atau menghambat tugas dan mata pencaharian bagi korbannya. ${ }^{23}$

\section{Kesimpulan}

Karakteristik kontrak kapitasi belum diatur secara rinci dan spesifik dalam peraturan perundang-undangan di Indonesia. Ketidakjelasan mengenai pengaturan kontrak kapitasi dalam system hukum di Indonesia menimbulkan pertanyaan

\footnotetext{
${ }^{21}$ F. Tengker dan S. Verbogt, Bab-Bab Hukum Kesehatan (Nova 1989).[56].

${ }^{22}$ Agus Budianto dan Gwendolyn Ingrid Utama, Aspek Jasa Pelayanan Kesehatan Dalam Perspektif Perlindungan Pasien (Karya Putra Darwati 2010).[129].

${ }^{23}$ ibid.[130].
} 
apakah isi dan pelaksanaan dari kontrak kapitasi tersebut tidak bertentangan dengan peraturanperundang-undangan yang telah ada. Karakteristik kontrak kapitasi dapat disimpulkan dari kontrak kapitasi yang telah dilaksanakan. Sebagai contoh, kontrak kapitasi yang dibuat antara PT. Petrokimia dengan PT. Petro Graha Medika berisi bahwa tujuan dibentuknya kontrak tersebut adalah untuk memberikan pelayanan kesehatan kepada Peserta yang dapat dilihat di Pasal 2 Kontrak mengenai lingkup pekerjaan. Maka, dapat disimpulkan bahwa karakteristik pertama yaitu para pihak yang ada dalam kontrak kapitasi yaitu rumah sakit sebagai pihak penyelenggara jasa layanan kesehatan kepada perusahaan sebagai pihak penerima jasa layanan kesehatan maupun dengan pihak ketiga yaitu perusahaan asuransi yang secara tidak langsung terlibat. Karakteristik kedua dalam kontrak kapitasi yaitu adanya pembayaran tetap yang diberikan oleh penerima jasa layanan kesehatan maupun pihak ketiga, yang dibayarkan di muka sebelum pelayanan kesehatan itu terjadi. Kontrak kapitasi termasuk dalam kontrak yang bersifat menguntungkan pihak ketiga. Kontrak kapitasi menekankan pada proses pelaksanaan kontrak itu dilakukan, bukan menekankan pada hasil dari pelaksanaan kontrak tersebut.

Implementasi kontrak kapitasi dalam pelaksanannya di Indonesia dilihat dari yang pertama mengenai keabsahannya. Syarat keabsahan suatu kontrak berdasarkan Pasal 1320 BW yaitu : 1) Kesepakatan; 2) Kecakapan; 3) Suatu hal tertentu; dan 4) Suatu sebab yang diperbolehkan. Berdasarkan penjelasan dalam penelitian ini, dapat disimpulkan bahwa kontrak kapitasi telah memenuhi keempat syarat sahnya suatu kontrak. Selain itu, kontrak kapitasi juga tidak melanggar peraturan perundang-undangan yang berkaitan dengan kontrak kapitasi seperti UU Kesehatan dan UU No. 3/1992, sehingga status kontrak kapitasi sah dan mempunyai kekuatan hukum mengikat para pihak yang membuatnya. Permasalahan kontrak kapitasi mengenai sistem pembayaran yang dianggap sama dengan perasuransian, sehingga dikatakan bahwa rumah sakit juga dianggap menjalankan usaha perasuransian menjadi tidak terbukti. Karena kontrak kapitasi ditujukan untuk menjamin pelayanan kesehatan, sehingga jasa pelayanan kesehatan bagi penderita (pasien) telah terjamin dan mencakup kelas perawatan pelayanan kesehatan diluar manfaat 
dari BPJS Kesehatan. Tanggung gugat dalam pelaksanaan kontrak kapitasi yaitu wanprestasi atau perbuatan melanggar hukum (PMH). Yang dapat mengajukan gugatan wanprestasi yaitu perusahaan sebagai pihak yang terikat dalam kontrak. Sedangkan yang dapat mengajukan gugatan PMH yaitu perusahaan ataupun pasien yang mengalami kerugian.

\section{Daftar Bacaan}

\section{Buku}

Agus Budianto dan Gwendolyn Ingrid Utama, Aspek Jasa Pelayanan Kesehatan Dalam Perspektif Perlindungan Pasien (Karya Putra Darwati 2010).

F. Tengker dan S. Verbogt, Bab-Bab Hukum Kesehatan (Nova 1989).

Gunawan Widjaja, Seri Hukum Bisnis Memahami Prinsip Keterbukaan (Aanvullend Recht) Dalam Hukum Perdata (RajaGrafindo Persada 2007).

Henni Djuhaeni, Asuransi Kesehatan Dan Managed Care: Modul Belajar Mengajar (Program Pascasarjana Magister Ilmu Kesehatan Masyarakat Universitas Padjajaran 2007).

Munawar Kholil, 'Modul Hukum Asuransi' (Universitas Negeri Sebelas Maret 2010)

Peter Zweifel, The Theory of Social Health Insurance (now Publishers Inc 2007)

Subekti, Aneka Perjanjian (Citra Aditya Bakti 1995).

Sulastomo, Manajemen Kesehatan (Gramedia Pustaka Utama 2007).

Suleman Batubara dan Orinton Purba, Arbitrase Internasional: Penyelesaian Sengketa Investasi Asing Melalui ICSID, UNCITRAL, Dan SIAC (Raih Asa Sukses 2013).

Hasbullah Thabary, 'Keterbukaan Dalam Pembayaran Kapitasi' (Universitas Indonesia 2014).

Theresa W. Bourdon, An Introduction to Capitation and Health Care Provider Excess Insurance (FCAS 1997).

\section{Jurnal}

I Gede Made Wintera dan Julita Hendrartini, 'Determinan Kepuasan Dokter 
Puskesmas Terhadap Sistem Pembayaran Kapitasi Peserta Wajib PT. Askes Di Kabupaten Donggala Provinsi Sulawesi Tengah' (2005) Vol. 08 Jurnal Manajemen Pelayanan Kesehatan.

Rachmad Suhanda, 'Jaminan Kesehatan Dan Managed Care' (2015) Vol. 2 Jurnal Universitas Padjajaran Bandung.

\section{Laman}

'BPJS Kesehatan' <http://www.bpjs-kesehatan.go.id/bpjs/index.php/pages/ detail/2014/13> accessed 15 January 2017.

Patrick C. Alguire, 'Understanding Capitation' (American College of Physicians) $<$ http://www.acponline.org/about-acp/about-internal-medicine/career-paths/ residency-career-counseling/guidance/understanding-capitation> accessed 13 September 2017.

\section{Perundang-undangan}

Undang-Undang Dasar Negara Republik Indonesia 1945.

Burgerlijk Wetboek (BW).

Undang-Undang Nomor 3 Tahun 1992 Tentang Jaminan Sosial Tenaga Kerja (Lembaran Negara Republik Indonesia Tahun 1992 Nomor 14, Tambahan Lembaran Negara Republik Indonesia Nomor 3468).

Undang-Undang Republik Indonesia Nomor 40 Tahun 2007 Tentang Perseroan Terbatas (Lembaran Negara Republik Indonesia Tahun 2007 Nomor 106, Tambahan Lembaran Negara Republik Indonesia Nomor 4756).

Undang-Undang Republik Indonesia Nomor 36 Tahun 2009 Tentang Kesehatan (Lembaran Negara Republik Indonesia Tahun 2009 Nomor 144, Tambahan Lembaran Negara Republik Indonesia Nomor 5063).

Undang-Undang Nomor 44 Tahun 2009 Tentang Rumah Sakit (Lembaran Negara Republik Indonesia Tahun 2009 Nomor 153, Tambahan Lembaran Negara Republik Indonesia Nomor 5072).

Undang-Undang Nomor 40 Tahun 2014 Tentang Perasuransian (Lembaran Negara Republik Indonesia Tahun 2014 Nomor 337, Tambahan Lembaran Negara Republik Indonesia Nomor 5618).

Peraturan Presiden Republik Indonesia Nomor 12 Tahun 2013 Tentang Jaminan Kesehatan (Lembaran Negara Republik Indonesia Tahun 2013 Nomor 29). 
Peraturan Presiden Republik Indonesia Nomor 32 Tahun 2014 Tentang Pengelolaan dan Pemanfaatan Dana Kapitasi Jaminan Kesehatan Nasional pada Fasilitas Kesehatan Tingkat Pertama Milik Pemerintah Daerah (Lembaran Negara Republik Indonesia Tahun 2014 Nomor 81).

HOW TO CITE: Andini Aprilia Wardhani dan Erni Agustin, 'Kontrak Kapitasi Dalam Hukum Kontrak Indonesia' (2018) Vol. 1 No. 2 Media Iuris. 